\title{
PROFILE OF PRIMARY HEADACHE PATIENTS IN NEUROLOGICAL POLYCLINIC
}

\author{
Yulia Damayanti ${ }^{1}$, Eko Arisetijono Marhaendraputro ${ }^{2}$, Widodo Mardi Santoso ${ }^{2}$, Dessika Rahmawati ${ }^{2}$ \\ ${ }^{I}$ Neurology Residency Program, Neurology Departement, Medical Faculty, Brawijaya University, Malang, Indonesia. \\ ${ }^{2}$ Neurology Department, Medical Faculty, Brawijaya University, Saiful Anwar General Hospital, Malang, Indonesia.
}

Correspondence: y.damay83@gmail.com

\begin{abstract}
Headache is the most common neurological disorder among all the symptoms of general health problems. Headaches are the most frequently complained of after back pain, which brings someone to the doctor and harms personal, family, social, quality of life, work, and finances. This study aims to find out the characteristics of primary headache patients in the neurological polyclinic, RSUD dr. Saiful Anwar Malang. The design of this research was an observational descriptive study of the filled headache questionnaire was to determine the characteristics of headache patients who visited the neurological polyclinic at dr. Saiful Anwar Malang with complaints of primary headache. The procedure of this research is to provide a questionnaire. The data analysis technique used is that the research variables will be presented in the frequency distribution table. The results of this research show that primary headache was more common in women as many as 19 people (61\%) compared to male 12 people (39\%). Most of the primary headache patients who came to the neurological clinic of Saiful Anwar Hospital were 30-60 years old. Tension-Type Headache (TTH) in this study had the highest percentage of 58\%. In this study, cluster headache two patients all attacked women.
\end{abstract}

Keyword : Primary headache, Nerves, Tension-type headache (TTH).

\section{INTRODUCTION}

Headache is the most common neurological disorder among all the symptoms of general health problems. Headaches are the most frequently complained of after back pain, which brings someone to the doctor and harms personal, family, social, quality of life, work, and finances. By definition, a headache is an uncomfortable sensation felt in the head area due to anything damaging or potentially causing structural damage. The area includes intracranial and extracranial (including the face), which have many pain-sensitive structures $(1,2)$. Headaches can be divided into primary headaches and secondary headaches. $90 \%$ of all headache complaints are primary headaches (2).

Primary headaches are headaches that are not the result of structural abnormalities in the intracranial region, in contrast to secondary headaches. Primary headache pain is usually recurrent with a particular pattern, and there is a trigger. Typical primary headache, in general, is that between attacks, there are usually no symptoms at all. Headaches are secondary, mainly if they occur at very close proximity to previous symptoms or other causes $(3,4)$.

The 2013 International Headache Society (IHS) classification divides headaches into primary, secondary, and cranial neuralgia. Primary headache consists of migraine, tension- type headache, cluster headache with trigeminal/autonomic cephalgia, and other primary headaches.

The characteristics of headaches vary widely in society, so this study aims to determine these variations, especially in patients who come to the neurological polyclinic at Saiful Anwar Hospital, as additional information about the primary headache epidemiology (5). This study aims to determine the characteristics of primary headache patients in the polyclinic nerves RSUD dr. Saiful Anwar Malang.

\section{METHODS}

\section{Meniere's Research's Design}

This type of research is a descriptive observational study of the filled headache questionnaire to determine the characteristics of headache patients visiting the neurological polyclinic at dr. Saiful Anwar Hospital Malang with complaints of primary headache.

\section{Population and Sample}

The population in this study were patients who visited the neurological polyclinic of dr. Saiful Anwar has complaints of primary headaches. In this study, using the purposive sampling technique, the sample was taken from all patient data which met the inclusion criteria.

Article History:

Received: January 25, 2021; Accepted: February 17, 2021; Published: March 1, 2021

Cite As:

Damayanti Y, Marhaendraputro EA, Santoso WM, Rahmawati D. Meniere's disease. Journal of Pain, Vertigo and Headache; 2021.1:1-4 
The sample used was patients who experienced primary headache complaints who visited the neurological clinic at Saiful Anwar Hospital Malang during 2019.

Table 1. Patient Inclusion and Exclusion Criteria

\begin{tabular}{|c|c|c|}
\hline Number & Inclusion Criteria & Exclusion Criteria \\
\hline 1 & $\begin{array}{c}\text { Primary headache } \\
\text { patients with both male } \\
\text { and female }\end{array}$ & $\begin{array}{l}\text { Primary headache } \\
\text { patients with both } \\
\text { male and female }\end{array}$ \\
\hline 2 & $\begin{array}{l}\text { Complete medical } \\
\text { records }\end{array}$ & $\begin{array}{l}\text { Complete medical } \\
\text { records }\end{array}$ \\
\hline 3 & $\begin{array}{l}\text { Agree on the Inform } \\
\text { Consent }\end{array}$ & $\begin{array}{c}\text { Agree on the Inform } \\
\text { Consent }\end{array}$ \\
\hline 4 & $\begin{array}{l}\text { Willing to fill out } \\
\text { questionnaires and } \\
\text { conduct interviews }\end{array}$ & \\
\hline
\end{tabular}

\section{The Data Collection}

This research was conducted in the neurological polyclinic of Syaiful Anwar Hospital Malang during 2019. The research variables to be analyzed descriptively and analytically in this study include age, gender, occupation, location of headache, headache time (duration and frequency), pain characteristics ( description of the headache, intensity (pain scale), triggers), medication when a headache, due to headache.

\section{The Data Analysis}

The procedure of this research is to provide a questionnaire. The questionnaire was given to patients with primary headache complaints who visited the neurological polyclinic of dr. Saiful Anwar, who met the requirements, became the research sample. The questionnaire was filled out simultaneously with the interview. The data from the questionnaire were then analyzed according to the variables and presented in diagrams and tables. The data analysis technique used is that the research variables will be presented in the frequency distribution table. Then the table will be analyzed descriptively.

\section{RESULT}

\section{Distribution of Patients by Gender and Age}

Of the 31 patients, it was found that $19(61 \%)$ were female, while the remaining $12(39 \%)$ were male. The distribution based on age shows the number of respondents aged $\leq 30$ years as six people $(19 \%)$, aged $>30-\leq 60$ years as many as 23 people $(74 \%)$ and those aged $>60$ years as many as two people $(7 \%)$. So from the distribution based on sex and age, it can be concluded that the female sex and the 30-60 year age group are the most groups.

Table 2. Distribution of Patients by Gender and Age

\begin{tabular}{lcc}
\hline \multirow{2}{*}{ Characteristics } & \multicolumn{2}{c}{ Total } \\
\cline { 2 - 3 } & Amount & $\&$ \\
\hline Age & & \\
\hline $\mathbf{3 3 0}$ yrs & 6 & 19 \\
\hline$>\mathbf{3 0}-\mathbf{5 6 0}$ yrs & 23 & 74 \\
\hline$>\mathbf{6 0}$ yrs & 2 & 7 \\
\hline Gender & & \\
\hline Male & 12 & 39 \\
\hline Female & 19 & 61 \\
\hline
\end{tabular}

\section{Distribution of patients by pain location}

The results for the location of headaches were the location of the two sides of the front head and the back head (it is like wearing a headband) 17 people (55\%), followed by locations on one side of the head as many as 13 people (42\%) and one person $(3 \%)$ had complaints on both sides of the head.

Table 3. Distribution based on the location of the headache

\begin{tabular}{ccc}
\hline Characteristics of & \multicolumn{3}{c}{ Total } \\
\hline Pain Location & Amount & $\%$ \\
One side & 13 & 42 \\
Two side & 1 & 3 \\
$\begin{array}{c}\text { Two sides of the front head } \\
\text { and the back of the head (the } \\
\text { location like wearing a } \\
\text { headband) }\end{array}$ & 17 & 55 \\
\hline
\end{tabular}

Distribution of Patients Based on Pain Characteristics

The most characteristic pain was pain, like being tied up in 18 people $(58 \%)$, followed by throbbing pain in 12 people $(38 \%)$ and one person (4\%) as stabbing pain.

Table 4. Distribution of Pain Characteristics

\begin{tabular}{lcc}
\hline \multicolumn{1}{c}{ Characteristics } & \multicolumn{2}{c}{ Total } \\
\hline Pain Characteristics & Amount & $\%$ \\
Throbbing & 12 & 38 \\
Like being stabbed & 1 & 4 \\
Like tied up & 18 & 58 \\
\hline
\end{tabular}

\section{Distribution of Patients Based on the Perceived Headache}

Scale

Based on the perceived headache scale, 14 people (45\%) felt headaches with a weight scale, namely 7-10 and was the most significant result, followed by 13 people (42\%) who felt headache on a moderate scale (4-6) and those who felt headache on a mild scale (1-3) in 4 people (13\%).

Table 5. Distribution by Headache Scale

\begin{tabular}{ccc}
\hline Characteristics of The scale & \multicolumn{2}{c}{ Total } \\
\cline { 2 - 3 } of the headache patients & Amount & $\%$ \\
\hline feel. & 4 & 13 \\
1-3 (light) & 13 & 42 \\
$7-10$ (hard) & 14 & 45 \\
\hline
\end{tabular}

\section{Distribution of Patients Based on Headache Triggers}

In this study, stress triggered the most headache attacks in 13 people $(42 \%)$, while the least triggering factor was sunlight, which affected one person (3\%). Even headaches could appear without any trigger in 6 people $(16 \%)$.

Tabel 6. Distribution of Patients Based on Headache Triggers

\begin{tabular}{ccc}
\hline \multirow{2}{*}{ Characteristics of Headache triggers } & \multicolumn{2}{c}{ Total } \\
\cline { 2 - 3 } & Amount & $\%$ \\
\hline Physical Activity & 8 & 26 \\
Stressor & 13 & 42 \\
Sunlight & 1 & 3 \\
Food & 0 & 0 \\
Lack of sleep & 4 & 13 \\
Not triggered by anything & 6 & 16 \\
\hline
\end{tabular}

\section{Distribution of Patients by Treatment}

Of the 31 people studied, $28(90 \%)$ took medication when a headache occurred, and only $3(10 \%)$ could endure their headache without taking medication when a headache occurred

Tabel 7. Distribution of Patients by Treatment

\begin{tabular}{ccc}
\hline Characteristics of Based on & \multicolumn{2}{c}{ Total } \\
\cline { 2 - 3 } treatment & Amount & $\%$ \\
Given medicine & 28 & 90 \\
Not given medicine & 3 & 10 \\
\hline
\end{tabular}




\section{Distribution of Patients Based on Headache Effects}

Headache disrupted activity in 23 people (74\%), and eight people $(26 \%)$ were not disturbed by their activities at the time of headache.

Tabel 8. Distribution of Patients Based on Headache Effects

\begin{tabular}{ccc} 
Characteristics of Due to & \multicolumn{2}{c}{ Total } \\
\cline { 2 - 3 } headaches & Amount & $\%$ \\
Interferes with activity & 23 & 74 \\
Does not interfere with activities & 8 & 26 \\
\hline
\end{tabular}

\section{Distribution of Patients by Type of Headache}

The most characteristic types of primary headache in this study were tension-type headaches (TTH), as many as 18 people $(58 \%)$, followed by migraine headaches as many as 11 people $(35 \%)$, and the least was the type of headache. The cluster of 2 people (7\%).

Tabel 9. Distribusi Berdasarkan Tipe Nyeri Kepala

\begin{tabular}{ccc}
\hline Characteristics of & Total \\
\hline Headache & Amount & $\%$ \\
Cluster & 2 & 7 \\
Migraine & 11 & 35 \\
Tension-Type Headache & 18 & 58 \\
$($ TTH) & & \\
\hline
\end{tabular}

\section{DISCUSSION}

Based on gender, this study's primary headache was more common in women as many as 19 people $(61 \%)$ compared to male 12 people $(39 \%)$. It is not much different from a study conducted in Maryland in 1994, which described the prevalence of headache in women as $53 \%$ and $27.5 \%$ in men for patients with primary headache.6 These results are consistent with other studies in India, in that study reported that the incidence of headache in women was about $66 \%$ from the Senthil study. A study in China also reported that female patients $(69.1 \%)$ dominated all headache patients. In most studies, female patients are more numerous than men, especially in TTH patients. It may be due to hormonal fluctuations, especially estrogen, which is closely related to headaches and usually increases headache pain during the premenstrual period and menstruation. Women are also said to have a lower threshold of Cortical Spreading Depression (CSD), which is believed to cause headaches $(7,8)$.

Most of the primary headache patients who come to the neurological clinic of Saiful Anwar Hospital are 30-60 years old. A study conducted by Kelman et al. states that the average age of headache patients, especially migraine headaches, is 37.67 years, with the youngest being 13 years and the oldest 80.5 years. A study from China conducted by Wang of 1683 headache patients also stated that the average age of headache was 44 years $(9,10)$.

The most headaches location was pain on both sides of the head and the back of the head (it is like wearing a headband) by $55 \%$. Following the headaches distribution, most are TTH, a tied headache location such as wearing a bandaged head (headband) (11,12).

Based on this study's most pain characteristics, pain like strapping was found in 18 patients (58\%), followed by throbbing pain in 12 patients $(38 \%)$. It is following a study conducted by Senthil et al., which stated that most headache patients had a type of pain that was pressing or binding $(8,9)$.
The pain scale felt at most was a scale of 7-10 (weight) as many as 14 patients (45\%), and the least was a scale of 1-3 (mild) in 4 patients (13\%). Patients with severe pain scale get the most results. The headache is very severe to interfere with the patient's daily activities so that it encourages patients to see a doctor, while patients with mild headaches prefer to delay getting checked out to the doctor because the pain that patients feel can disappear by taking medication or the pain does not interfere with activities $(10,11)$.

The most trigger of primary headache in patients who came to the neurological clinic of Saiful Anwar Malang Hospital was stress as much as $42 \%$, physical activity by $26 \%$, and the lowest was due to the trigger of sunlight by $3 \%$. Stress can cause respiratory hyperventilation so that the $\mathrm{CO} 2$ level in the blood decreases. Alkalosis occurs, which results in calcium ions entering the cells and causing excessive muscle contraction resulting in headaches $(8,12)$.

Tension-Type Headache (TTH) in this study had the highest percentage of $58 \%$. This study follows the theory that Tension-Type Headache (TTH) is the most common, with prevalence in the general population ranging between $30 \%$ and $78 \%$ in different studies (13-15). Cluster headache was obtained in at least two patients (7\%). In this study, cluster headache two patients all attacked women. It is not under the existing theory which says that cluster headache incidence in men is more than in women, namely $6: 1$ (16-18).

\section{CONCLUSION}

Based on the results of research and discussion, it can be concluded that most cases of primary headaches are tensiontype headaches (TTH), most of which provide pain characteristics such as being tied to the head with the most significant cause of stress. The majority of primary headache cases occur in women in the 30-6 year age group.

Further studies with prospective methods and using more research samples. Further research is related to the relationship and correlation of stress with the incidence of primary headaches in patients with a neurology clinic at Saiful Anwar Hospital Malang.

\section{ACKNOWLEDGMENT}

The authors are thanks to Brawijaya University and RSUD dr. Saiful Anwar Malang gives a chance to do this research.

\section{CONFLICT OF INTEREST}

The authors declare that there is no conflict of interest.

\section{REFERENCES}

1. Lindsay KW, Al. E. Headache neurology and neurosurgery illustrated. London: Churchill Livingstone; 2004. 66-72

2. Azzahra AZ, Purwanti E, Hanik B. Expert system design as a tool for early diagnosis of primary head pain. Malang Neurol J; 2017. 3:78-87.

3. Aninditha T, Wiratman W. Headache. In: Neurology Textbook. Jakarta: Department of Neurology, Faculty of Medicine, University of Indonesia; 2017. p. 569-97. 
4. Sjahrir H, Suharjanti I, Al E. Diagnosis and management of headache. in: national consensus $\mathrm{V}$ headache study group, Indonesian Association of Neuroscientists. Jakarta; 2018.

5. Rozen TD, Fishman RS. Female cluster headache in the United States of America: What are the gender differences? Results from the United States cluster headache survey. J Neurol Sci; 2012. 317(1-2):17-28.

6. Ravat S, Chaudhari S, Chafekar N. Clinical profile of primary headaches and awareness of trigger factor in migraine patients. MVP J Med; 2018. 5(2):145-50.

7. Hassan M, Asaad T. Tension-type headache, its relation to stress, and how to relieve it by cryotherapy among academic students. Middle East Curr Psychiatry; 2020. 27(20):3-11.

8. Stovner LJ, Hagen K, Jensen R, Katsarava Z, Lipton RB, Scher A. The global burden of headache: A documentation of headache prevalence and disability worldwide. Cephalalgia; 2007. 27:193-210.

9. Hsu LC, Wang SJ, Fuh JL. Prevalence and impact of migrainous vertigo in mid-life women: A communitybased study. Cephalalgia; 2011. 31(1):77-83.

10. Iliopoulos P, Damigos D, Kerezoudi E, et al. Trigger factors in primary headaches subtypes: A crosssectional study from a tertiary center in Greece. BMC Res Notes; 2015. 8:393-402.
11. Brunton, LL. Goodman and Gilman's Pharmacology. Boston: McGraw-Hill; 2006.

12. Hauser S.L. Harrison's neurology in clinical medicine. 3rd edition. New York: McGraw-Hill; 2013.

13. King S.D, Katherina C, Herndon. Headache disorder in pharmacotherapy a pathophysiologic approach. McGraw-Hill Companies; 2005.

14. Hidayati HB. Carbamazepine as a pain treatment of trigeminal neuralgia. Journal of Pain, Headache, and Vertigo (JPHV); 2020. 1:37-41.

15. Hidayati HB, Kustriyani A. Paracetamol, migraine, and medication overuse headache (moh). Journal of Pain, Headache, and Vertigo (JPHV); 2020. 1:42-47.

16. Kurniawan SN, Suriani N, Marhaedraputro EK, Rahmawati D. Myofascial pain syndrome. Journal of Pain, Headache, and Vertigo (JPHV); 2020. 1:17-21.

17. Tepper, S.J. Editorial: International classification of headache disorder. Headache; 2013. 53:1381-1382.

18. Ginsberg, Lionel. Lectures Notes Neurologi. Ed. Ke-8. Erlangga: Jakarta, 2008.

19. Stephen D, Silberstein. Wolff's Headache and Other Head Ache. London : Oxford University Press; 2001. 